\title{
Impact of Pruning and Agronomical Management on Wood Production and Yield of Paddy under Dalbergia sissoo Roxb. Based Agroforestry System
}

\author{
Sudha Patel ${ }^{1}$, Neelam Bisen ${ }^{2 *}$, K. K. Jain ${ }^{3}$ and C. P. Rahangdale ${ }^{3}$
}

${ }^{1}$ Dept. of Agronomy, ${ }^{3}$ Dept. of Forestry, Jawaharlal Nehru Agriculture University, Jabalpur, Madhya Pradesh (482 004), India, ${ }^{2}$ Dept. of Agronomy, IAS, Banaras Hindu University, Varanasi, Uttar Pradesh (221 005), India

\section{Corresponding Author}

Neelam Bisen

e-mail: neelam.bisen25@gmail.com

\author{
Article History \\ Manuscript No. AR1807 \\ Received in $9^{\text {th }}$ April, 2017 \\ Received in revised form $18^{\text {th }}$ May, 2017 \\ Accepted in final form $7^{\text {th }}$ June, 2017
}

\begin{abstract}
The field experiment was conducted at the Research Farm, of New Dusty Acre Area, Department of Forestry, College of Agriculture, JNKVV, Jabalpur (M.P.) during, kharif season of 2014. The experiment involve four pruning intensities+one open (without tree) in main plot and Three agronomical management practices in sub plot under strip plot design with five replications. The results revealed that, the growth and yield attributing parameters of paddy were significantly varied due to the effect of different pruning treatments and agronomical management practices. Among all the treatments open condition (crop only) produced significantly higher grain and straw yield (24.8 q ha-1 and $37.7 \mathrm{q} \mathrm{ha}^{-1}$, respectively). Under agronomical management system $25 \%$ more nitrogen produced significantly higher grain and straw yield $\left(21.6 \mathrm{q} \mathrm{ha}^{-1}\right.$ and $\left.36.2 \mathrm{q} \mathrm{ha}^{-1}\right)$. It was found that the diameter at breast height (Dbh) of tree was significantly influenced by different pruning treatments. $25 \%$ pruning recorded significantly higher $\mathrm{dbh}(23.98 \mathrm{~cm})$. The cylindrical volume and stand biomass of tree significantly influenced by different pruning treatments, $25 \%$ pruning recorded significantly higher cylindrical volume $\left(217.27 \mathrm{~m}^{3} \mathrm{ha}^{-1}\right)$ and stand biomass ( $167301.31 \mathrm{~kg} \mathrm{ha}^{-1}$ ), which was significantly superior to $75 \%$ pruning and at pt par with no pruning and $50 \%$ pruning. The present study suggested that shade of trees adversely affects growth and yield of crop but silvicultural operation which can reduce tree canopy, facilitated entry of sunlight, pruning is one of them.
\end{abstract}

Keywords: Paddy, D. sissoo, agroforestry, pruning intensity, agronomical management

\section{Introduction}

Paddy (Oryza sativa L.), is the most widely consumed staple food for a large part of the world's human population, especially in Asia. India is an important centre of paddy cultivation. In India, paddy is grown on nearly 42410 ha area and having production of 157800 tonnes and productivity of $3721 \mathrm{~kg} \mathrm{ha}^{-1}$ (GOI, 2014). The food grain production in India has been doubled during the past green revolution period without increasing the net cultivated area. This marvelous achievement is mainly due to increased better agronomical management practices like fertilizers, pesticides and herbicides. Fertilizer is an expensive and precious input, determination of an appropriate dosage of application that would be both economical and appropriate to enhance productivity and consequent profit of the grower. Nitrogen is very essential for the growth and development of crops. Nitrogen absorbed by rice during the vegetative growth stages contributed in growth during reproduction and grainfilling through translocation. Dalbergia sissoo Roxb. is a medium to large sized tree belonging to family Leguminosae and subfamily Papilionioideae. It attains a height upto 30 $\mathrm{m}$. This genus has about 300 species of tropical and subtropical timber tree species. It is having multiple uses such as fuel, wood, fodder, shade, and nitrogen fixing ability. The species occur throughout the Sub-Himalayan tract and outer Himalayan valleys from Indus to Assam, usually upto $900 \mathrm{~m}$ and occasionally ascending to $1500 \mathrm{~m}$.

Pruning is a common silvicultural practice to increase wood production, improve tree shape and potentially uses to obtain poles and fire wood without decrease in wood productivity. Pruning of tree component is a powerful approach to regulate light, nutrients and other resource competition (Frank and Eduaro, 2003, Dhillon et al., 2010). Many scientists reported the effect of height and intensity of pruning on biomass production. It improves wood quality and tree stem shape. Pruning decreased the tree taper and increases the volume and medium pruning intensity has highest volume increment (Rani et al., 2011; Manhas et al., 2011. Agroforestry may be one of the solutions to increase forest area to one third of the total geographical area of our country. The present forest 
area of the country $69.7 \mathrm{mha}(23.82 \%)$ is not in a position to meet out the present demand of fuel, fodder, timber, raw material for small and large scale industry and forest products (Dhyani, 2013). The agrisilviculture (tree+crop) system is more productive and sustainable than agriculture. There are many MPTS which can be used in agroforestry system, Dalbergia sissoo is one of them. The agricultural crops, which can be grown in combination with Sissoo, are maize, mustard, rapeseed, gram, peas, wheat, rice, sugarcane and cotton etc. Shade intensity has strong negative effects on the performance of under storey crops. Light is a critical factor affecting the performance of field crops under agroforestry intervention. Pruning has become an essential practice for reducing both above and below ground competition with associated crops (Sinclair and Luther, 1998, Bari and Rahim, 2010). In tree crop system, canopy pruning alleviate shading of crops and appeared as an effective mean of increasing the light permeability to under storey crops (Newaj et al., 2007). Biomass yields and productivity of crops have also been reported higher under pruned trees (Dropplemann and Berliner, 2003). Keeping above facts in view, the present investigation was carried out.

\section{Materials and Methods}

The field experiment was conducted at Dusty acre area, under AICRP on Agroforestry project, Department of Forestry Jawaharlal Nehru Krishi Vishwa Vidyalaya, Jabalpur (M.P.). Jabalpur lies between $22^{\circ} 49^{\prime}$ to $24^{\circ} 8^{\prime}$ North Latitude and $78^{\circ} 21^{\prime}$ to $80^{\circ} 58^{\prime}$ East Longitude with an attitude of 411.78 $\mathrm{m}$ MSL. It comes under the agro-climate region classified as Kymore Plateau and Satpura Hills and is broadly known as Rice-Wheat crop zone of Madhya Pradesh. The climate of the region is semi and with hot dry summer and cold dry winter. The soil of the experimental area was medium black, clay loam in texture, neutral in reaction ( $\mathrm{pH} 5.90)$, medium in organic carbon (0.84), medium in available nitrogen (289.6 $\left.\mathrm{kg} \mathrm{ha}^{-1}\right)$, high in available phosphorus (20.30 kg ha-1) and very low in Potash (171.42 $\mathrm{kg} \mathrm{ha}^{-1}$ ). The experiment was conducted during rainy season under 16 years old Dalbergia sissoo planted at a distance of $5 \times 5 \mathrm{~m}^{2}$ during 1998. The experiment involve four pruning intensities viz., no pruning, 25, 50 and $75 \%$ pruning in Dalbergia sissoo+one open (without tree) in main plot and Three agronomical management practices i.e., $F_{1}$ Recommended dose of fertilizer (120:60:40 NPK kg $\left.\mathrm{ha}^{-1}\right)+$ Seed rate $\left(80 \mathrm{~kg} \mathrm{ha}^{-1}\right), \mathrm{F}_{1}+25 \%$ more nitrogen than the recommended dose of fertilizer, $\mathrm{F}_{1}+25 \%$ more seed rate than the recommended dose of seed rate in sub plot under strip plot design with 5 replications. All the observations on crop were recorded before harvesting and at the time of harvesting. Tree observations were also recorded. The crop and tree parameter were analyzed statistically using analysis of variance for strip plot design. The significance was tested for all the parameters at $5 \%$ level.

\section{Results and Discussion}

\subsection{Growth parameters}

\subsubsection{Effect of pruning intensities}

The growth parameters viz., plant height and number of tillers $\mathrm{m}^{-2}$ were recorded at 30,60, 90 DAS and at harvest (Table 1). The rate of growth was most rapid in vegetative phase upto 90 days after sowing and slows in reproductive phase. Effect of different pruning intensities in $D$. sissoo produced significant effect on plant height $(\mathrm{cm})$ in all successive intervals of growth at 30, 60, 90 DAS and at harvest. Plant under open condition i.e. crop without tree recorded significantly the tallest plant

Table 1: Impact of different pruning intensities of $D$. sissoo, and agronomical management practices on plant height $(\mathrm{cm})$ and number of tillers $\mathrm{m}^{-2}$ at 30,60, 90 days after sowing and at harvest under agrisilviculture system

\begin{tabular}{|c|c|c|c|c|c|c|c|c|}
\hline \multirow{3}{*}{$\begin{array}{l}\text { Treat- } \\
\text { ments }\end{array}$} & \multicolumn{4}{|c|}{ Plant height $(\mathrm{cm})$} & \multicolumn{4}{|c|}{ No. of tillers $\mathrm{m}^{-2}$} \\
\hline & 30 & 60 & 90 & At & 30 & 60 & 90 & At \\
\hline & DAS & DAS & DAS & $\begin{array}{l}\text { Har- } \\
\text { vest }\end{array}$ & DAS & DAS & DAS & $\begin{array}{l}\text { har- } \\
\text { vest }\end{array}$ \\
\hline \multicolumn{9}{|c|}{ Pruning Intensities } \\
\hline $\mathrm{T}_{1}$ & 20.1 & 47.6 & 73.1 & 72.8 & 20.1 & 47.6 & 73.1 & 72.8 \\
\hline $\mathrm{T}_{2}$ & 21.3 & 49.3 & 75.0 & 74.3 & 21.3 & 49.3 & 75.0 & 74.3 \\
\hline $\mathrm{T}_{3}$ & 23.2 & 50.8 & 76.6 & 76.1 & 23.2 & 50.8 & 76.6 & 76.1 \\
\hline $\mathrm{T}_{4}$ & 23.9 & 53.7 & 78.1 & 77.7 & 23.9 & 53.7 & 78.1 & 77.7 \\
\hline $\mathrm{T}_{5}$ & 25.2 & 55.2 & 80.6 & 80.3 & 25.2 & 55.2 & 80.6 & 80.3 \\
\hline SEm \pm & 0.6 & 1.1 & 0.8 & 0.9 & 0.6 & 1.1 & 0.8 & 0.9 \\
\hline$C D^{*}$ & 1.9 & 3.4 & 2.3 & 2.7 & 1.9 & 3.4 & 2.3 & 2.7 \\
\hline \multicolumn{9}{|c|}{ Agronomical management practices } \\
\hline $\mathrm{S}_{1}$ & 21.2 & 49.4 & 75.1 & 74.6 & 21.2 & 49.4 & 75.1 & 74.6 \\
\hline $\mathrm{S}_{2}$ & 24.2 & 53.1 & 78.3 & 77.8 & 24.2 & 53.1 & 78.3 & 77.8 \\
\hline $\mathrm{S}_{3}$ & 22.8 & 51.4 & 76.6 & 76.3 & 22.8 & 51.4 & 76.6 & 76.3 \\
\hline SEm \pm & 0.5 & 0.9 & 0.6 & 0.5 & 0.5 & 0.9 & 0.6 & 0.5 \\
\hline$C D^{*}$ & 1.6 & 2.8 & 1.9 & 1.6 & 1.6 & 2.8 & 1.9 & 1.6 \\
\hline
\end{tabular}

$\mathrm{T}_{1}$ : No pruning; $\mathrm{T}_{2}: 25 \%$ pruning; $\mathrm{T}_{3}: 50 \%$ pruning; $\mathrm{T}_{4}: 75 \%$ pruning; $\mathrm{T}_{5}$ : Open-(Only crop); $\mathrm{S}_{1}: \mathrm{F}_{1}$ (RDF and RSD); $\mathrm{S}_{2}$ : $\mathrm{F}_{1}+25 \%$ more nitrogen; $\mathrm{S}_{3}: \mathrm{F}_{1}+25 \%$ more seed rate; $C D^{*}: C D$ $(p=0.05)$

height $25.2,55.2,80.6,80.3 \mathrm{~cm}$ at 30, 60, 90 DAS and at harvest respectively as compared to crop grown under tree with different pruning intensities. This may be due to the fact that tree canopy could have affected the penetration of light and due to shading effect on the understorey annual crops, growth is affected it is also reported by Dropplemann and Berliner (2003). Among pruning intensities (no pruning, 25\%, $50 \%$ and $75 \%$ pruning), $75 \%$ pruning recorded significantly 
tallest plant height $(23.9,53.7,78.1,77.7 \mathrm{~cm})$ followed by $50 \%$ pruning $(23.2,50.8,76.6,76.1 \mathrm{~cm})$ and $25 \%$ pruning $(21.3,49.3,75.0,74.3 \mathrm{~cm})$ at $30,60,90$ DAS and at harvest. No pruning recorded significantly shorter plant (20.1, 47.6, $73.1,72.8 \mathrm{~cm})$ than other pruning $(25 \%, 50 \%$ and no pruning) treatments. Dropplemann and Berliner (2003) also recorded the same results in agroforestry system. In all the observations open condition (crop without tree) recorded significantly higher number of tillers per $\mathrm{m}^{2}$ at 30 DAS (290.0), 60 DAS (387.6), 90 DAS (425.7) and at harvest (424.4) than the plant grown under trees with different pruning intensities, No pruning recorded significantly lowest number of tillers per $\mathrm{m}^{2}$ at 30 DAS (244.5), 60 DAS (326.7), 90 DAS (371.3) and at harvest (370.8). Among different pruning intensities, $75 \%$ pruning recorded significantly higher number of tillers per $\mathrm{m}^{2}$ (371.9) which was significantly superior to $50 \%$ pruning (356.0) at 60 DAS but at par at 30, 90 DAS and at harvest. Crop under no pruning (maximum shade) recorded lowest number of tiller per $\mathrm{m}^{2}$ (326.7). Newaj et al. (2007) reported that plant height and number of branches were highest in $70 \%$ pruning and lowest in unpruned i.e. control.

\subsubsection{Effect of agronomical management practices}

During the study period it was observed that, $25 \%$ more nitrogen than recommended dose of fertilizer and seed rate recorded maximum plant height at $30(24.2 \mathrm{~cm}), 60(53.1$ $\mathrm{cm}), 90(78.3 \mathrm{~cm})$ and at harvest $(77.8 \mathrm{~cm})$ stage of plant growth, which was at par with $25 \%$ more seed rate than recommended dose of seed rate and fertilizer dose and both were significantly superior to recommended dose of fertilizer and seed rate (Table 1). Ray and Mishra (1999) also suggested that the higher nitrogen level recorded significantly higher plant height than other nitrogen treatment.

\subsection{Yield attributing characters}

\subsubsection{Effect of pruning intensities}

It is obvious from the results that number of effective tillers $\mathrm{m}^{-2}$, length of panicle, grains panicle $\mathrm{e}^{-1}$, number of filled grain panicle $^{-1}$, sterility percentage and 1000 grain weight varied significantly due to different pruning intensities (Table 2). Open condition (sole crop) recorded significantly maximum number of effective tillers $\mathrm{m}^{-2}$ (264.7), length of panicle (22.1 $\mathrm{cm})$, grains panicle ${ }^{-1}$ (159.5), number of filled grains (120.4), sterility percentage $(24.6 \%)$ and 1000 grain weight $(22.3 \mathrm{~g})$ as compared to crop grown with trees under different pruning intensities. The probable reason for higher number of tillers $\mathrm{m}^{-2}$, panicle length in open condition was that more light was available which helped in photosynthesis, multiplication of cells as a result it produced more length of panicle. Similar results were also found by Puri et al. (2001). Among different pruning intensities, $75 \%$ pruning intensities recorded significantly higher yield attributes viz., number of effective tillers $\mathrm{m}^{-2}$ (256.7), length of panicle (21.7), grains panicle ${ }^{-1}$ (158.5), number of filled grain (116.2) and 1000 grain weight. All the yield attributing characteristics (Number of effective tillers $\mathrm{m}^{-2}$, Length of panicle $\mathrm{cm}$, Grains panicle ${ }^{-1}$, Number of filled grain and 1000 grain weight) decreased with decreased in pruning intensities, hence, no pruning having significantly lowest number of effective tillers $\mathrm{m}^{-2}$ (216.7), length of panicle (18.8), grains panicle ${ }^{-1}$ (151.4), number of filled grain (101.9) and 1000 grain weight $(19.3 \mathrm{~g})$. In agrisilviculture system, pruning at suitable age had vital importance to get maximum production of intercrops due to more light transmission to crop, otherwise, the yield will be reduced. The benefit of pruning has been recognized by several workers (Islam et al., 2006; Newaj et al., 2005).

\subsubsection{Effect of agronomical management practices}

In all yield attributing characters viz., number of effective tillers $\mathrm{m}^{-2}$, length of panicle, grains panicle ${ }^{-1}$, number of filled grains panicle $^{-1}, 1000$ grain weight (except sterility percentage) were influenced by different level of fertilizer dose and seed rate. $25 \%$ more fertilizer dose than recommend dose of fertilizer recorded number of effective tillers $\mathrm{m}^{-2}$ (243.6), length of panicle $(21.6 \mathrm{~cm})$, grains panicle ${ }^{-1}(156)$, number of filled grains panicle $^{-1}(112.2)$ and 1000 grain weight (22.0 g) was significantly superior recommended fertilizer dose and seed rate and at par with $25 \%$ more seed rate than recommended dose of fertilizer and seed rate (Table 2). Phiji et al. (2012) also reported the similar results.

\subsection{Grain and straw yield}

\subsubsection{Effect of pruning intensities}

In the present study crop grown under open condition (without tree) recorded significantly highest grain yield $\left(24.8 \mathrm{q} \mathrm{ha}^{-1}\right)$ as compared to crop grown with trees under different pruning treatments (Table 2). The probable reason for higher yield under open condition was that, in open condition maximum sunlight, was available which resulted in maximum number of tillers $\mathrm{m}^{-2}$ (424.4), number of effective tillers $\mathrm{m}^{-2}$ (264.7), plant height $(80.3 \mathrm{~cm})$ and length of panicle $(22.1 \mathrm{~cm})$, as compared to other pruning treatments having different shade areas, as a result it produced higher grain yield. Sharma (2003) reported the similar results. Among different pruning intensities, grain yield increased with increasing pruning intensities. Among pruning intensities, significantly maximum grain yield was recorded under $75 \%$ pruning $\left(22.2 \mathrm{q} \mathrm{ha}^{-1}\right)$ which in turn was superior to $25 \%\left(14.9 \mathrm{q} \mathrm{ha}^{-1}\right)$ and no pruning $\left(12.4 \mathrm{q} \mathrm{ha}^{-1}\right)$ and at par with $50 \%\left(19.1 \mathrm{q} \mathrm{ha}^{-1}\right)$. The probable reason might be due to more availability of light in $75 \%$ pruning. Canopy pruning increased the availability of photosynthetically active radiation (PAR) and reduced the competition for light which increased the rate of photosynthesis in crop plants resulted in accumulation of more photosynthates in plant and their translocation from source to sink. The result is inconformity with find of Handa and Rai (2002). No pruning gave lowest grain yield ( $\left.12.4 \mathrm{q} \mathrm{ha}^{-1}\right)$; it may be due to more canopy spread as compared to others. Significantly highest straw yield (37.7 $\mathrm{q} \mathrm{ha} \mathrm{a}^{-1}$ ) of paddy was recorded when grown without tree (open condition) as compared to crop grown with tree under 
Table 2: Yield attributing parameters and yield of paddy as affected by different pruning intensities and agronomical management practices under agrisilviculture system

\begin{tabular}{|c|c|c|c|c|c|c|c|c|c|}
\hline $\begin{array}{l}\text { Treat- } \\
\text { ments }\end{array}$ & $\begin{array}{c}\text { No. of } \\
\text { effective } \\
\text { tillers }\left(\mathrm{m}^{-2}\right)\end{array}$ & $\begin{array}{l}\text { Length of } \\
\text { panicle } \\
(\mathrm{cm})\end{array}$ & $\begin{array}{l}\text { Grains } \\
\text { panicle }^{-1}\end{array}$ & $\begin{array}{l}\text { No. of filled } \\
\text { grains panicle }{ }^{-1}\end{array}$ & $\begin{array}{l}\text { Sterility } \\
(\%)\end{array}$ & $\begin{array}{l}1000 \text { grain } \\
\text { weight }(\mathrm{g})\end{array}$ & $\begin{array}{l}\text { Grain } \\
\text { yield } \\
\left(q \text { ha }^{-1}\right)\end{array}$ & $\begin{array}{c}\text { Straw } \\
\text { yield } \\
\left(q \text { ha }^{-1}\right)\end{array}$ & $\begin{array}{c}\text { Harvest } \\
\text { index } \\
(\%) \\
\end{array}$ \\
\hline \multicolumn{10}{|c|}{ Pruning Intensities } \\
\hline $\mathrm{T}_{1}$ & 216.7 & 18.8 & 151.4 & 101.9 & 32.7 & 19.3 & 12.4 & 26.3 & 30.8 \\
\hline $\mathrm{T}_{2}$ & 223.0 & 19.7 & 151.7 & 105.9 & 29.3 & 20.1 & 14.9 & 32.0 & 31.8 \\
\hline$T_{3}$ & 230.0 & 20.7 & 153.4 & 110.2 & 27.6 & 20.9 & 19.1 & 33.1 & 36.6 \\
\hline $\mathrm{T}_{4}$ & 256.7 & 21.7 & 158.5 & 116.2 & 26.5 & 21.3 & 22.2 & 36.7 & 37.7 \\
\hline $\mathrm{T}_{5}$ & 264.7 & 22.1 & 159.5 & 120.4 & 24.6 & 22.3 & 24.8 & 37.7 & 39.7 \\
\hline SEm \pm & 6.4 & 0.4 & 1.8 & 1.5 & 0.4 & 0.6 & 2.4 & 2.6 & 1.9 \\
\hline $\begin{array}{l}C D \\
(p=0.05)\end{array}$ & 19.1 & 1.3 & 5.5 & 4.5 & 1.3 & 1.9 & 7.2 & 7.7 & 5.6 \\
\hline \multicolumn{10}{|c|}{ Agronomical management practices } \\
\hline $\mathrm{S}_{1}$ & 231.4 & 19.6 & 153.0 & 109.5 & 29.0 & 19.0 & 15.5 & 29.9 & 34.3 \\
\hline $\mathrm{S}_{2}$ & 243.6 & 21.6 & 156.0 & 112.2 & 27.0 & 22.0 & 21.6 & 36.2 & 37.4 \\
\hline $\mathrm{S}_{3}$ & 239.6 & 20.6 & 155.2 & 111.0 & 28.3 & 21.4 & 19.0 & 34.6 & 35.3 \\
\hline SEm \pm & 2.4 & 0.3 & 0.7 & 0.6 & 0.3 & 0.5 & 0.6 & 1.5 & 0.8 \\
\hline $\begin{array}{l}C D \\
(p=0.05)\end{array}$ & 7.9 & 0.9 & 2.3 & 1.8 & 0.9 & 1.6 & 2.2 & 4.6 & 2.5 \\
\hline
\end{tabular}

different pruning treatment. This may be due to the fact that, open condition produced taller plants and more number of tillers per $\mathrm{m}^{2}$, therefore, higher straw yield was obtained. $75 \%$ pruning recorded maximum straw yield at par with $50 \%$ pruning which inturn was superior to $25 \%$ and no pruning. Newaj et al. (2005) also observed the same results.

\subsubsection{Effect of agronomical management practices}

Different level of fertilizer dose and seed rate affected the yield of crop. Treatment $\mathrm{S}_{2}$ i.e., $25 \%$ more fertilizer dose than recommended dose of fertilizer and seed rate gave significantly higher grain yield $\left(21.6 \mathrm{q} \mathrm{ha}^{-1}\right)$ which was significantly superior to treatment $\mathrm{S}_{3}$ i.e., $25 \%$ more seed rate than recommended dose of fertilizer and seed rate (19.0 q $\mathrm{ha}^{-1}$ ) and treatment S1 i.e. recommended dose of fertilizer dose and seed rate $\left(15.5 \mathrm{q} \mathrm{ha}^{-1}\right)$. The probable reason of higher grain yield was due to higher yield attributing characters viz., number of effective tillers $\mathrm{m}^{-2}$ (243.6), length of panicle (21.6 $\mathrm{cm})$, grains panicle ${ }^{-1}$, number of filled grains panicle ${ }^{-1}(112.2)$, test weight $(22.0 \mathrm{~g})$ and lower sterility percentage $(27.0 \%)$. The straw yield is resultant of plant height and tillers in behaviour of the crop. Treatment $\mathrm{S}_{2}$ i.e., $25 \%$ more fertilizer dose than recommended dose of fertilizer produced significantly highest straw yield $\left(36.2 \mathrm{q} \mathrm{ha}^{-1}\right)$ at par with treatment $\mathrm{S}_{3}$ i.e., $25 \%$ more seed rate than recommended dose of fertilizer and seed rate $\left(34.6 \mathrm{q} \mathrm{ha}^{-1}\right)$. Recommended dose of fertilizer and seed rate recorded significantly lowest straw yield $\left(29.9 \mathrm{q} \mathrm{ha}^{-1}\right)$. The Probable reason of higher yield in both treatments was due to more plant height and number of tillers per $\mathrm{m}^{2}$ compared to recommended dose of fertilizer and seed rate.

\subsection{Harvest index (\%)}

Different pruning intensities showed significant effect on grain yield and biological yield (Table 2). In open condition more grain straw ratio was found than the other pruning treatments. This may be due to proportionately more production of grain and straw in open condition as compared to other pruning treatments which recorded lower grain and biological yield. Among pruning treatments, $75 \%$ pruning recorded significantly highest harvest index (37.7\%) than other intensities of pruning due to more grain yield as compared to the pruning intensities. In treatment $\mathrm{S}_{2}$ i.e., $25 \%$ more nitrogen than recommended dose of fertilizer and seed rate significantly higher harvest index (37.4\%) was noted whereas, treatment $S_{1}$ i.e., recommended dose of fertilizer and seed rate recorded the lowest harvest index (34.3\%). The probable reason of higher harvest index in treatment $\mathrm{S}_{2}$ as compared to treatment $S_{1}$ i.e., recommended dose of fertilizer and seed rate was due to more grain yield in treatment $S_{2}$ as compared to treatment $\mathrm{S}_{1}$ and $\mathrm{S}_{3}$.

\subsection{Morphological characters of Shisham}

\subsubsection{Effect of pruning intensities}

Pruning treatment showed no significant effect on tree height. Similar results were also reported by Couto and Gomes (1995). The dbh of tree was significantly influenced by different 
pruning treatments. $25 \%$ pruning recorded significantly higher $\mathrm{dbh}(23.98 \mathrm{~cm})$ while $75 \%$ pruning recorded significantly lower $\mathrm{dbh}(17.28 \mathrm{~cm})$. The probable reason of lower $\mathrm{dbh}$ value in $75 \%$ pruning may be due to heavy pruning leads to greater removal of leaf area than light pruning and strongly reduces the overall carbohydrate production of a tree. This implies that pruning reduces both the production and the consumption of the carbohydrates, which affect the tree growth adversely (Bredenkamp et al., 1980). In the present study tree growth interms of $\mathrm{dbh}$, height and crown diameter was lowest in $75 \%$ pruning and increased with reduced pruning intensities. Canopy spread in both $\mathrm{N}-\mathrm{S}$ and $\mathrm{E}-\mathrm{W}$ directions were significantly influenced by pruning treatment. No pruning recorded significantly higher canopy spread in both directions. The percent reduction in canopy spread in $\mathrm{N}-\mathrm{S}$ direction in 25 , 50 and $75 \%$ pruning as compared to no pruning was $38.89 \%$, $46.30 \%$ and $63.89 \%$, respectively. Similarly, the percent reduction in canopy spread in $\mathrm{E}-\mathrm{W}$ direction from no pruning to 25,50 and further $75 \%$ pruning was $18.18 \%, 24.55 \%$ and $40.90 \%$ respectively (Table 3 ). Overall tree growth was better in the agrisilviculture system than pure tree (without crop), this was probably due to fact that trees also benefited from irrigation, fertilizer and tillage operations given to the crop. A similar result was given by Newaj et al., 2007.

Pruned biomass was significantly influenced by different pruning treatment. Trees having heavy pruning i.e., 75\% pruning recorded highest pruned biomass (2010 $\mathrm{kg} \mathrm{ha}^{-1}$ ) as compared to $50 \%$ pruning (1864 $\mathrm{kg} \mathrm{ha}^{-1}$ ) and $25 \%$ pruning $\left(1668 \mathrm{~kg} \mathrm{ha}^{-1}\right)$. Biomass production is directly correlated with pruning intensity. Hence, pruned trees tended to produce more biomass as compared to lightly pruned trees. The reason is simple that more foliage was removed in $75 \%$ pruning which increased the pruned biomass. Similar results have also been reported by Zeng (2001). Cylindrical volume of standing trees was significantly influenced by different pruning treatments in D. sissoo. $25 \%$ pruning recorded significantly higher cylindrical volume $\left(217.27 \mathrm{~m}^{3} \mathrm{ha}^{-1}\right)$ at par with no pruning (192.55 $\mathrm{m}^{3} \mathrm{ha}^{-1}$ ) and 50\% pruning (187.22 $\mathrm{m}^{3} \mathrm{ha}^{-1}$ ) but significantly superior to $75 \%$ pruning $\left(100.87 \mathrm{~m}^{3} \mathrm{ha}^{-1}\right)$. Cylindrical volume is ultimate product of height and $\mathrm{dbh}$ of tree. This was due to fact that trees are commonly pruned by removing leaves and branches from lower part of the crown

Table 3: Morphological growth characters and biomass production of $D$. sissoo as influenced by different pruning intensities and different agronomical practices in agri-silviculture system at the age of 16 years

\begin{tabular}{|c|c|c|c|c|c|c|c|}
\hline \multirow[t]{2}{*}{ Treatments } & \multirow{2}{*}{$\begin{array}{c}\text { Tree height } \\
\text { (m) }\end{array}$} & \multirow{2}{*}{$\begin{array}{l}\mathrm{dbh}_{-1.37 \mathrm{~m}} \\
(\mathrm{~cm})\end{array}$} & \multicolumn{2}{|c|}{ Canopy spread (m) } & \multirow{2}{*}{$\begin{array}{l}\text { Pruned } \\
\text { biomass } \\
\left(\mathrm{kg} \mathrm{ha}^{-1}\right)\end{array}$} & \multirow{2}{*}{$\begin{array}{l}\text { Cylindrical } \\
\text { volume }\left(\mathrm{m}^{3} \mathrm{ha}^{-1}\right)\end{array}$} & \multirow{2}{*}{$\begin{array}{l}\text { Stand biomass } \\
\qquad\left(\mathrm{kg} \mathrm{ha}^{-1}\right)\end{array}$} \\
\hline & & & $\mathrm{N}-\mathrm{S}$ & E-W & & & \\
\hline \multicolumn{8}{|c|}{ Pruning Intensities } \\
\hline $\mathrm{T}_{1}$ & 10.56 & 24.05 & 10.8 & 11.0 & - & 192.55 & 148262.13 \\
\hline $\mathrm{T}_{2}$ & 11.92 & 23.98 & 6.6 & 9.0 & 1668.0 & 217.27 & 167301.31 \\
\hline $\mathrm{T}_{3}$ & 11.31 & 22.71 & 5.8 & 8.3 & 1864.0 & 187.22 & 144160.56 \\
\hline $\mathrm{T}_{4}$ & 10.06 & 17.28 & 3.9 & 6.5 & 2010.0 & 100.87 & 77671.59 \\
\hline $\mathrm{T}_{5}$ & 0.59 & 1.67 & 0.2 & 1.3 & 141.24 & 26.78 & 20619.01 \\
\hline SEm \pm & NS & 5.34 & 0.6 & 4.2 & 451.74 & 85.65 & 65949.24 \\
\hline \multicolumn{8}{|c|}{ Agronomical management practices } \\
\hline $\mathrm{S}_{1}$ & 10.9 & 22.2 & 6.0 & 9.3 & 1422.0 & 177.7 & 136864.5 \\
\hline $\mathrm{S}_{2}$ & 11.0 & 22.0 & 5.90 & 8.6 & 1386.0 & 172.0 & 132410.3 \\
\hline $\mathrm{S}_{3}$ & 11.0 & 21.8 & 5.90 & 8.0 & 1450.0 & 171.3 & 131885.7 \\
\hline SEm \pm & 11.0 & 22.0 & 6.00 & 8.8 & 1284.0 & 176.9 & 136235.1 \\
\hline $\mathrm{CD}(p=0.05)$ & 0.18 & 0.63 & 0.1 & 0.25 & 95.42 & 8.85 & 6818.25 \\
\hline $\begin{array}{l}\mathrm{S}_{1}-\mathrm{F}_{1}(\mathrm{RDF} \\
\text { and } \mathrm{RSD})\end{array}$ & NS & NS & NS & NS & NS & NS & NS \\
\hline
\end{tabular}

RDF: Recommended dose of fertilizer; RSR: Recommended seed rate

which changes the stem shape to a more cylindrical form and increases the clear bole length, resulting in more biomass allocation in bole than other components. The similar results were also reported by Pinkard et al. (2004). Stand biomass was significantly influenced by different pruning intensities $25 \%$ pruning recorded significantly highest stand biomass (167301.31 $\mathrm{kg} \mathrm{ha}^{-1}$ ) as compared to no pruning (148262.13 $\left.\mathrm{kg} \mathrm{ha}^{-1}\right), 50 \%$ (144160.56 kg ha-1) and 75\% pruning (77671.59 $\left.\mathrm{kg} \mathrm{ha}^{-1}\right)$. In $25 \%$ pruning highest cylindrical volume (217.27 $\mathrm{m}^{3} \mathrm{ha}^{-1}$ ) was recorded. The probable reason may be due to more $\mathrm{dbh}(23.98 \mathrm{~cm})$ and maximum height $(11.92 \mathrm{~m})$ the stand biomass is the resultant value of height and $\mathrm{dbh}$. The results clearly showed that more pruning reduced biomass production and this reduction has positive correlation with 
amount of pruning. Most likely, this reduction may be due to the diminished photosynthesis of pruned trees, because pruning of branches leads to a decrease in remaining leaf area and to a decrease in the number of buds from which new branches and leaves can be produced. Similar results also reported by Pinkard et al. (1999).

\subsubsection{Effect of agronomical management practices}

Different level of fertilizer dose and seed rate showed no significant effect on tree height, dbh, canopy spread (N-S and $\mathrm{E}-\mathrm{W})$, pruned biomass, cylindrical volume and stand biomass. The probable reason may be that the fertilizer, irrigation and cultural practices applied which were utilized by crop itself and negligible amount utilized by trees, hence showed no effect on growth parameters of tree. The results were inconformity with Karwar et al. (2006).

\section{Conclusion}

$75 \%$ pruning produced significantly maximum grain yield $\left(22.2 \mathrm{q} \mathrm{ha}^{-1}\right)$ and straw yield $\left(36.7 \mathrm{q} \mathrm{ha}^{-1}\right)$ followed by $50 \%$ and $25 \%$ pruning. $25 \%$ more nitrogen than recommended dose of fertilizer and seed rate gave significantly higher grain yield (21.6 $\left.\mathrm{q} \mathrm{ha}^{-1}\right)$ and straw yield $\left(36.2 \mathrm{ha}^{-1}\right) .25 \%$ pruning led to record the highest plant height $(11.92 \mathrm{~cm})$, cylindrical volume (217.27 $\left.\mathrm{m}^{3} \mathrm{ha}^{-1}\right)$ and stand biomass (167301.31 kg ha-1).

\section{Acknowledgement}

Authors are thankful to project coordinator, AICRP on Agroforestry for encouragement and providing facilities. Financial assistance provided by ICAR is greatly acknowledged.

\section{References}

Bari, B.S., Rahim, A.M., 2010. Production potential of ginger under different spacing of Dalbergia sissoo Journal of Agroforestry and Environment. 4 (1), 143-146.

Bredenkamp, B.V., Malan, F.S., Conradie, W.E., 1980. Some effects of pruning on growth and timber quality of Eucalyptus grandis in Zuzuland. South African Forestry Journal 114, 29-34.

Couto, L., Gomes, J.M., 1995. Intercropping of Eucalyptus with beans in Minas Gerais, Brazil. International Tree Crop Journal 8, 83-93.

Dhillon, W.S., Srinidhi, H.V., Chauhan, S.K., Singh, C., Singh, N., Jabeen, N., 2010. Micro-envoriment and physiology of turmeric cultivated under poplar tree canopy. Indian Journal of Agroforestery, 12(2), 23-37.

Dhyani, S.K., Handa, A.K., Uma., 2013. Area under agroforestry in India: An Assessment for present status and future perspective. Indian Journal of Agroforestry 15(1), 164-187.

Dropplemann, K., Berliner, P., 2003. Runoff agroforestry-a technique to secure the livelihood of pastoralists in the Middle East. Journal of Arid Environments 54, 571-577.

Frank, E., Eduardo, S., 2003. Biomass dynamics of Erythrina lanceolata as influenced by shoot pruning intensity in Costa Rica. Agroforestry System 57, 19-28.
GOI., 2014. Agricultural Statistics at a Glance 2014, Oxford University Press YMCA Library Building, 1 Jai Singh Road, New Delhi 110 001, India.

Handa, A.K., Rai, P., 2002. Agrisilviculture studies under rainfed conditions. Annual Report, NRCAF, Jhansi, 12-14.

Islam, K.K., Hoque, A.T.M.R., Mamum, M.F., 2006. Effect of level of pruning on the performance of rice-sissoo based agroforestry system. American Journal of Plant Physiology 1(1), 13-20.

Karwar, G.R., Pratibha, V.R., Palani Kunwar, D., 2006. Performance of castor (Ricinus communis) and green gram (Vigna radiate) in agroforestry system in semi arid tropics. Indian Journal of Agronomy 51(2), 112-115.

Manhas, S.S., Gill, B.S., Sharma, Sushil and Kumar, Krishan., 2011. Effect of pruning material, planting dates and harvesting dates on growth, yield and quality of turmeric. Indian Journal of Horticulture 689(2), 229-234.

Newaj, R., Dar, S.A., Bhargava, M.K., Yadav, R.S., Ajit, 2007. Effect of management practices on growth of white siris (Albizia procera), grain yield of intercrops, weed population and soil fertility changes in agrisilviculture system in semi-arid India. Indian Journal of Agricultural Sciences 77(7), 403-407.

Phiji, P., Jha, G., Singh, P., Singh, S., 2012. Effect of Different Nitrogen Levels on Newly Developed Rice Varieties under Transplanted Condition. Agricultural Science Digest 32(1), 75-78.

Pinkard, E.A., Mohammed, C.L., Hall, M.F., Worledge, D., Nollon, A., 2004. Growth responses, physiology and decay associated with pruning plantation-grown Eucalyptus globules Labill and E. nintens (Deane and Maiden) Maiden. Forest Ecology and Management, 200, 263-270.

Pinkard, E.A., Battagalia, M., Beadle, C.L., Sanda, P.J., 1999. Modeling the effect of physiological responses to green pruning on net biomass production of Eucalyptus nitens, Tree Physiology 19, 1-12.

Puri, S., Rao, B., Swamy, S.L., 2001. Growth and productivity of wheat varieties in an agrisilviculture system. Indian Journal of Agroforestry 3(2), 134-138.

Rani, S., Chauhan, S.K., Kumar, R., Dhatt, K.K., 2011. Bioeconomic appraisal of flowering annuals for seed production under poplar (Populus deltoides) based agroforestry system. Tropical Agricultural Research, 22, 125-133.

Ray, D.K., Mishra, S.S., 1999. Effect of weed management in direct seeded upland rice at varying nitrogen levels. Indian Journal of Agronomy 44(1), 105-108.

Sharma, B.M., 2003. Productivity of grains, legumes in agrisilviculture system under hot arid conditions. Advances in Arid legumes Research, 279-284.

Sinclair, T.R., Luther, C.H., 1998. Transpiration rate of soybean on sandy soil. Agronomy Journal 90, 363-368.

Zeng, B., 2001. Pruning Chinese Tree: an experimental and modeling approach. Tekst- Proefschrift Universities Utrecht 173, 135-144. 